Article

\title{
Genome-Wide Transcriptional and Functional Analysis of Human T Lymphocytes Treated with Benzo[ $\alpha]$ pyrene
}

\author{
Marie Liamin ${ }^{1,2}$, Hélène Le Mentec ${ }^{1,2}$, Bertrand Evrard ${ }^{1}$, Laurence Huc ${ }^{3}$, Frédéric Chalmel ${ }^{1}$, \\ Elisa Boutet-Robinet ${ }^{3}\left(\mathbb{D}\right.$, Eric Le Ferrec ${ }^{1,2}$ and Lydie Sparfel ${ }^{1,2, *(D)}$ \\ 1 Institut National de la Santé et de la Recherche Médicale (INSERM), Institut de Recherche en Santé, \\ Environnement et Travail (IRSET-INSERM UMR 1085), 35000 Rennes, France; \\ marie.liamin@univ-rennes1.fr (M.L.); helene.le-mentec@univ-rennes1.fr (H.L.M.); \\ bertrand.evrard@inserm.fr (B.E.); frederic.chalmel@univ-rennes1.fr (F.C.); \\ eric.leferrec@univ-rennes1.fr (E.L.F.) \\ 2 Université de Rennes 1, Faculté des Sciences Pharmaceutiques et Biologiques, Structure Fédérative de \\ Recherche Biosit UMS CNRS 3480/US INSERM 018, 35043 Rennes, France \\ 3 Toxalim (Research Centre in Food Toxicology), Université de Toulouse, INRA, ENVT, INP-Purpan, UPS, \\ 31027 Toulouse, France; laurence.huc@inra.fr (L.H.); elisa.boutet@univ-tlse3.fr (E.B.-R.) \\ * Correspondence: lydie.sparfel@univ-rennes1.fr; Tel.: +33-2-23-23-47-63; Fax: +33-2-23-23-47-94
}

Received: 13 November 2018; Accepted: 16 November 2018; Published: 17 November 2018

\begin{abstract}
Polycyclic aromatic hydrocarbons (PAHs) are widely distributed environmental contaminants, known to affect $\mathrm{T}$ lymphocytes. However, the molecular targets and pathways involved in their immunotoxic effects in human T lymphocytes remain unknown. Here, we analyzed the gene expression profile of primary human $\mathrm{T}$ lymphocytes treated with the prototypical PAH, benzo $[\alpha]$ pyrene $(\mathrm{B}[\alpha] \mathrm{P})$, using a microarray-based transcriptome analysis. After a $48 \mathrm{~h}$ exposure to $\mathrm{B}[\alpha] \mathrm{P}$, we identified 158 genes differentially expressed in T lymphocytes, including not only genes well-known to be affected by PAHs such as the cytochromes P450 (CYP) 1A1 and 1B1, but also others not previously shown to be targeted by $\mathrm{B}[\alpha] \mathrm{P}$ such as genes encoding the gap junction beta $(G J B)-2$ and 6 proteins. Functional enrichment analysis revealed that these candidates were significantly associated with the aryl hydrocarbon (AhR) and interferon (IFN) signaling pathways; a marked alteration in T lymphocyte recruitment was also observed. Using functional tests in transwell migration experiments, $\mathrm{B}[\alpha] \mathrm{P}$ was then shown to significantly decrease the chemokine $(\mathrm{C}-\mathrm{X}-\mathrm{C}$ motif) ligand 12-induced chemotaxis and transendothelial migration of $\mathrm{T}$ lymphocytes. In total, this study opens the way to unsuspected responsive pathway of interest, i.e., T lymphocyte migration, thus providing a more thorough understanding of the molecular basis of the immunotoxicity of PAHs.
\end{abstract}

Keywords: benzo[ $\alpha]$ pyrene; T lymphocytes; microarrays; migration; immunotoxicity

\section{Introduction}

Benzo $[\alpha]$ pyrene $(\mathrm{B}[\alpha] \mathrm{P})$ is a prototypical polycyclic aromatic hydrocarbon $(\mathrm{PAH})$ that is formed by incomplete combustion of organic materials. It is found in large amounts in diet, air pollution, cigarette smoke and some occupational atmospheres [1]. Human exposure to this widespread environmental contaminant has been correlated to various pathological situations such as cancer development, and inflammation contributing to cardiovascular and pulmonary diseases $[2,3]$. Therefore, $\mathrm{B}[\alpha] \mathrm{P}$ has been classified as a priority toxicant by the United States Environmental Protection Agency, the World Health Organization and the European Union. Most of the $\mathrm{B}[\alpha]$ P-related toxic effects have been linked to the activation of the aryl hydrocarbon receptor (AhR) and its subsequent binding to 
specific xenobiotic responsive elements within the promoter of responsive genes [4]. For example, the activation of the AhR-related signaling pathway by $\mathrm{B}[\alpha] \mathrm{P}$ results in the up-regulation of xenobiotic metabolizing enzymes such as cytochromes P-450 (CYPs) 1A1, 1A2 and 1B1; this in turn bioactivates $\mathrm{B}[\alpha] \mathrm{P}$ into epoxide derivatives that largely account in a major way for carcinogenic effects in several organs such as lung, liver and lymphoid tissue [5].

Among cell types targeted by $\mathrm{B}[\alpha] \mathrm{P}$, lymphocytes, in particular T cells which express AhR and possess a CYP1-metabolizing system [6,7] appear to be a major one. Early in vitro and in vivo studies using rodent models reported $\mathrm{B}[\alpha] \mathrm{P}$-mediated immunotoxic effects such as suppression of antibody production in response to a T-dependent antigen [8], decrease in T-cell responses to mitogens [9], or inhibition of cytotoxic T-lymphocyte generation and natural killer cell activity [10]. Such alterations of immune resistance mechanisms that interfere with $\mathrm{T}$ lymphocyte functions have been postulated to facilitate tumor development in responsive animals [11]. In humans, the $\mathrm{B}[\alpha] \mathrm{P}$ capacity to modulate immune function has been less characterized, and data that specifically demonstrate its immunosuppressive effects towards response of human T lymphocytes, are more limited [12,13]. Most studies using human T lymphocytes mainly reported the presence of DNA adducts upon $\mathrm{B}[\alpha] \mathrm{P}$ exposure that may influence cancer development $[14,15]$. However, the link with $\mathrm{T}$ lymphocyte immune response remains to be deciphered. Recently, we have reported an up-regulation of AhR expression and activity in primary cultures of human $\mathrm{T}$ lymphocytes by the physiologically relevant T-cell stimulation by anti-CD3 and anti-CD28 antibodies [7]. We have also demonstrated that this up-regulation is associated with an increased capacity to metabolize PAHs such as $\mathrm{B}[\alpha] \mathrm{P}$, thereby producing specific DNA damage and increasing mutation frequency [16]. Altogether, our data propose primary activated human $T$ lymphocytes as a good model to analyze human health issues depending on the environment. Using a microarray-based transcriptome analysis of activated human T lymphocytes, the present study aims at characterizing global transcriptional alterations after exposure to $\mathrm{B}[\alpha] \mathrm{P}$, and identifying signaling pathways and biological functions affected by this PAH. We report that $\mathrm{B}[\alpha] \mathrm{P}$ impacts essential functions of adaptive immune responses such as the interferon (IFN) signaling pathway and $\mathrm{T}$ lymphocyte recruitment.

\section{Results}

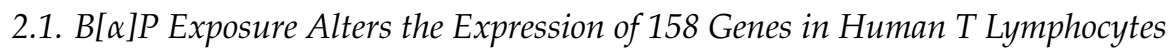

To determine the effect of $\mathrm{B}[\alpha] \mathrm{P}$ on the gene signature in human $\mathrm{T}$ lymphocytes, primary cultures of $\mathrm{T}$ lymphocytes purified from healthy blood donors and activated with anti-CD3 and anti-CD28 antibodies for $72 \mathrm{~h}$, were used and co-exposed to $2 \mu \mathrm{M} \mathrm{B}[\alpha] \mathrm{P}$ for the last $48 \mathrm{~h}$. We previously reported an early and functional up-regulation of the AhR by such human T lymphocyte activation during $24 \mathrm{~h}$ [7], followed by a maximal response of target genes such as CYP1A1 and CYP1B1 after exposure to $2 \mu \mathrm{M} \mathrm{B}[\alpha] \mathrm{P}[7,16]$. Such a $2 \mu \mathrm{M}$ concentration is in the range of $\mathrm{B}[\alpha] \mathrm{P}$ concentrations known to lead to maximal response of target genes in cultured human cells $[17,18]$. In addition and in agreement with our previous results, such a $\mathrm{B}[\alpha] \mathrm{P}$ exposure for $48 \mathrm{~h}$ did not significantly alter lymphocyte viability $[7,16]$.

Using equal amounts of RNAs pooled from 16 independent $\mathrm{T}$ lymphocyte cultures into 4 equimolar pools and considering the criteria of selection described in the Materials and Methods section, we were able to identify 158 genes displaying significant signal changes after a $48 \mathrm{~h}$ treatment with $2 \mu \mathrm{M}$ B $[\alpha] \mathrm{P}$ (Figure 1). The full list of these genes is given in Supplementary Table S1. Among these differentially expressed genes, 97 and 61 were found to be up-regulated and down-regulated upon $\mathrm{B}[\alpha] \mathrm{P}$ treatment, respectively. The top 15 most up-regulated and down-regulated genes are summarized in Table 1. Among these genes, as expected [7,16], CYP1A1 and CYP1B1, well-known targets of AhR [4], appear as the top genes over-expressed after exposure to $\mathrm{B}[\alpha] \mathrm{P}$, thus validating our experimental conditions. 


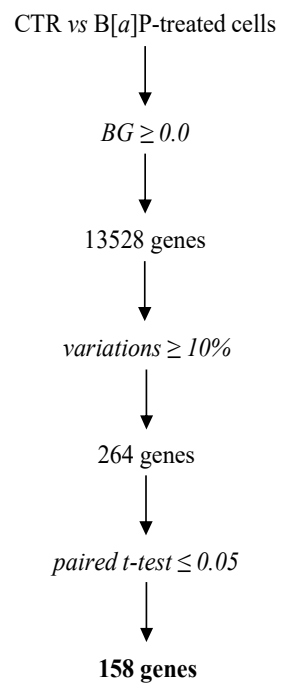

Figure 1. Transcriptomic analysis of differentially expressed genes in $\mathrm{B}[\alpha] \mathrm{P}$-treated T lymphocytes. A flow chart outlines our procedure to filter genes that display statistically significant signal changes when DMSO (CTR) and $\mathrm{B}[\alpha]$ P-treated samples were compared.

Table 1. Top 15 up-regulated and down-regulated genes after treatment of human T lymphocytes with $2 \mu \mathrm{M} \mathrm{B}[\alpha] \mathrm{P}$ for $48 \mathrm{~h}$.

\begin{tabular}{|c|c|c|c|c|}
\hline ID & Gene Name & Description & $\begin{array}{c}\text { Differential } \\
\text { Expression (log-2) a }\end{array}$ & $p$-Value \\
\hline \multicolumn{5}{|c|}{ Top 15 up-regulated genes } \\
\hline 1543 & CYP1A1 & cytochrome P450, family 1 , subfamily A, polypeptide 1 & 1.152 & $5.9 \times 10^{-3}$ \\
\hline 1545 & CYP1B1 & cytochrome P450, family 1 , subfamily B, polypeptide 1 & 1.058 & $4.7 \times 10^{-3}$ \\
\hline 2706 & GJB2 & gap junction protein, beta $2,26 \mathrm{kDa}$ & 0.702 & $5.7 \times 10^{-3}$ \\
\hline 10804 & GJB6 & gap junction protein, beta $6,30 \mathrm{kDa}$ & 0.528 & $7.7 \times 10^{-3}$ \\
\hline 25976 & TIPARP & TCDD-inducible poly (ADP-ribose) polymerase & 0.528 & $1.0 \times 10^{-2}$ \\
\hline 153339 & TMEM167A & transmembrane protein 167A & 0.491 & $3.0 \times 10^{-2}$ \\
\hline 167826 & OLIG3 & oligodendrocyte transcription factor 3 & 0.484 & $2.7 \times 10^{-2}$ \\
\hline 91768 & CABLES1 & Cdk5 and Abl enzyme substrate 1 & 0.426 & $3.1 \times 10^{-4}$ \\
\hline 3815 & KIT & proto-oncogene c-Kit & 0.401 & $1.2 \times 10^{-5}$ \\
\hline 51676 & ASB2 & ankyrin repeat and SOCS box containing 2 & 0.388 & $5.6 \times 10^{-4}$ \\
\hline 83888 & FGFBP2 & fibroblast growth factor binding protein 2 & 0.362 & $2.0 \times 10^{-3}$ \\
\hline 5774 & PTPN3 & protein tyrosine phosphatase, non-receptor type 3 & 0.349 & $1.1 \times 10^{-2}$ \\
\hline 9289 & ADGRG1 & adhesion G protein-coupled receptor G1 & 0.346 & $5.8 \times 10^{-3}$ \\
\hline 23682 & $R A B 38$ & RAB38, member RAS oncogene family & 0.328 & $4.6 \times 10^{-3}$ \\
\hline 81618 & ITM2C & integral membrane protein $2 \mathrm{C}$ & 0.307 & $1.5 \times 10^{-2}$ \\
\hline \multicolumn{5}{|c|}{ Top 15 down-regulated genes } \\
\hline 10964 & IFI44L & interferon-induced protein 44 -like & -0.451 & $1.7 \times 10^{-2}$ \\
\hline 1293 & COL6A3 & collagen, type VI, alpha 3 & -0.337 & $6.3 \times 10^{-3}$ \\
\hline 10561 & IFI44 & interferon-induced protein 44 & -0.322 & $3.2 \times 10^{-2}$ \\
\hline 79648 & MCPH1 & microcephalin 1 & -0.319 & $1.0 \times 10^{-2}$ \\
\hline 1130 & LYST & lysosomal trafficking regulator & -0.282 & $2.2 \times 10^{-2}$ \\
\hline 4599 & MX1 & MX dynamin-like GTPase 1 & -0.282 & $4.8 \times 10^{-2}$ \\
\hline 8638 & OASL & $2^{\prime}-5^{\prime}$-oligoadenylate synthetase- & -0.269 & $2.0 \times 10^{-3}$ \\
\hline 3433 & IFIT2 & $\begin{array}{l}\text { interferon-induced protein with tetratricopeptide } \\
\text { repeats } 2\end{array}$ & -0.267 & $5.6 \times 10^{-4}$ \\
\hline
\end{tabular}


Table 1. Cont.

\begin{tabular}{|c|c|c|c|c|}
\hline ID & Gene Name & Description & $\begin{array}{c}\text { Differential } \\
\text { Expression (log-2) a }\end{array}$ & $p$-Value \\
\hline 10216 & PRG4 & proteoglycan 4 & -0.266 & $3.4 \times 10^{-2}$ \\
\hline 7070 & THY1 & Thy- 1 cell surface antigen & -0.265 & $1.0 \times 10^{-2}$ \\
\hline 6402 & SELL & selectin L & -0.233 & $3.1 \times 10^{-2}$ \\
\hline 56479 & KCNQ5 & $\begin{array}{l}\text { potassium channel, voltage gated KQT-like subfamily Q, } \\
\text { member } 5\end{array}$ & -0.232 & $1.7 \times 10^{-2}$ \\
\hline 1803 & $D P P 4$ & dipeptidyl-peptidase 4 & -0.222 & $2.3 \times 10^{-2}$ \\
\hline 3394 & IRF8 & interferon regulatory factor 8 & -0.220 & $1.2 \times 10^{-2}$ \\
\hline 5167 & ENPP1 & ectonucleotide pyrophosphatase/phosphodiesterase 1 & -0.207 & $2.1 \times 10^{-2}$ \\
\hline
\end{tabular}

We then performed RT-qPCR assays using the same equimolar pools of RNAs as those in microarray experiments, in order to confirm transcriptional changes observed for candidate genes selected from the transcriptome analysis. We thus selected the most significantly affected genes: CYP1A1 and 1B1, gap junction beta-2 (GJB2) and beta-6 (GJB6) proteins, TCDD-inducible poly(ADP-ribose) polymerase (TIPARP), transmembrane protein 167A (TMEM167A), oligodendrocyte transcription factor 3 (OLIG3), cyclin-dependent kinase-binding protein (CABLES1), proto-oncogene $c-K I T$ and E3 ubiquitin ligase specificity subunit (ASB2) for the 10 most up-regulated genes; IFN-induced proteins 44L (IFI44L), 44 (IFI44), p78 (MX1) with tetratricopeptide repeats 2 (IFIT2), collagen (COL6A3), microcephalin MCPH1, lysosomal trafficking regulator (LYST), enzyme oligoadenylate synthetase like (OASL), proteoglycan (PRG4), and cell surface antigen (THY1) for the 10 most down-regulated ones. The direction of changes in mRNA expression determined by RT-qPCR closely matched the microarray data for all the genes tested, except for TMEM167A which rather showed a down-regulated expression (Figure 2). Thus, CYP1A1, CYP1B1, GJB2, GJB6, TIPARP, OLIG3, CABLES1, KIT and ASB2 transcriptional levels were confirmed to be up-regulated after $\mathrm{B}[\alpha] \mathrm{P}$ exposure; with inductions reaching a significant level for all these genes except for OLIG3 and TIPARP (Figure 2A). RT-qPCR analysis also reported the decrease in expression of the most down-regulated genes identified by our microarray study with a significant effect for IFI44L, IFI44, MX1, OASL, PRG4, IFIT2 and THY1 (Figure 2B). 

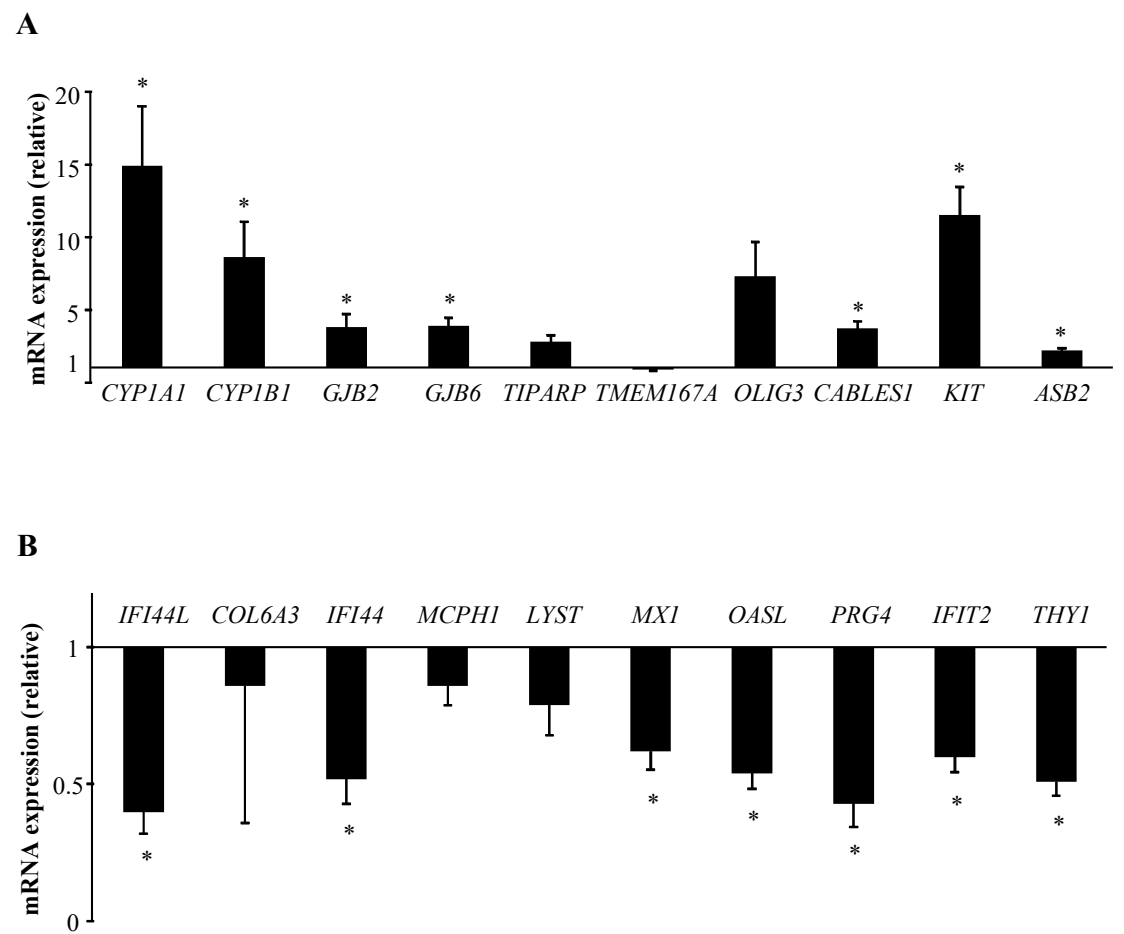

Figure 2. Validation by RT-qPCR analysis of the 10 most significantly up-regulated (A) and the 10 most significantly down-regulated (B) genes identified by microarray experiments after treatment of human T lymphocytes with $2 \mu \mathrm{M} \mathrm{B}[\alpha] \mathrm{P}$ for $48 \mathrm{~h}$. Primary human T lymphocytes activated for $72 \mathrm{~h}$ were treated with DMSO (CTR) or with $2 \mu \mathrm{M} \mathrm{B}[\alpha] \mathrm{P}$ for the last $48 \mathrm{~h}$ of culture. mRNA expression was analyzed using RT-qPCR. Data are expressed relative to mRNA expression level in CTR T lymphocytes, arbitrarily set at 1 unit, and are shown as mean \pm SEM of 4 independent experiments performed on the same pools of RNAs isolated from CTR or B $[\alpha]$ P-treated cultures as those used in microarray experiments, with triplicate per experiment. ${ }^{*} p \leq 0.05$ when compared with CTR T lymphocytes (paired Student's $t$ test).

2.2. The AhR and IFN Signalling are the Most Significant Canonical Pathways Regulated by B[ $\alpha] P$ in Human T Lymphocytes

In order to investigate global signaling pathways affected by $\mathrm{B}[\alpha] \mathrm{P}$ exposure, the 97 up-regulated and the 61 down-regulated transcripts were next submitted to the IPA software. This analysis revealed that "AhR signaling", "Protein Kinase A signaling", "Estrogen-mediated S-phase entry" and "Cell cycle: G1/S checkpoint regulation" pathways were the four most significant pathways in the gene set up-regulated by B $[\alpha] \mathrm{P}$ exposure. Regarding the down-regulated genes, the "IFN signaling", the "granulocyte adhesion and diapedesis", the "role of pattern recognition receptors in recognition of bacteria and viruses", and the "activation of IFN regulatory transcription factor (IRF) by cytosolic pattern recognition receptors' pathways were the most significant pathways regulated by $\mathrm{B}[\alpha] \mathrm{P}$ exposure (Table 2). 
Table 2. Top canonical pathways regulated after treatment of human T lymphocytes with $2 \mu \mathrm{M} \mathrm{B}[\alpha] \mathrm{P}$ for $48 \mathrm{~h}$.

\begin{tabular}{|c|c|c|}
\hline Top Pathways & ${ }^{\text {a }} p$-Value & b Regulated Genes \\
\hline \multicolumn{3}{|c|}{ Up-regulated genes } \\
\hline $\begin{array}{l}\text { Aryl Hydrocarbon Receptor } \\
\text { Signaling }\end{array}$ & $3.99 \times 10^{-5}$ & $\begin{array}{c}\text { AhRR, CCNE2, CDKN1A, CYP1A1, } \\
\text { CYP1B1, NQO1 }\end{array}$ \\
\hline Protein Kinase A Signaling & $7.36 \times 10^{-5}$ & $\begin{array}{l}\text { ADCY9, ADD2, DUSP4, MYH10, MYL9, } \\
\text { PPP1R14C, PTPDC1, PTPN3, SAMD3 }\end{array}$ \\
\hline Estrogen-mediated S-phase entry & $2.06 \times 10^{-4}$ & CCNE2, CDKN1A, E2F7 \\
\hline $\begin{array}{l}\text { Cell cycle: } \mathrm{G} 1 / \mathrm{S} \text { checkpoint } \\
\text { regulation }\end{array}$ & $2.14 \times 10^{-4}$ & CCNE2, CDKN1A, E2F7, SAMD3 \\
\hline \multicolumn{3}{|c|}{ Down-regulated genes } \\
\hline Interferon Signaling & $1.41 \times 10^{-4}$ & IFIT3, MX1, OAS1 \\
\hline $\begin{array}{l}\text { Granulocyte Adhesion and } \\
\text { Diapedesis }\end{array}$ & $1.74 \times 10^{-4}$ & $\begin{array}{c}\text { CCL3, CCL3L3, CCL4L1, CCL4L2, } \\
\text { SELL, THY1 }\end{array}$ \\
\hline $\begin{array}{l}\text { Role of Pattern Recognition } \\
\text { Receptors in Recognition of } \\
\text { Bacteria and Viruses }\end{array}$ & $5.97 \times 10^{-4}$ & DDX58, IFIH1, OAS1, OSM \\
\hline $\begin{array}{l}\text { Activation of IRF by Cytosolic } \\
\text { Pattern Recognition Receptors }\end{array}$ & $7.42 \times 10^{-4}$ & DDX58, IFIH1, IFIT2 \\
\hline
\end{tabular}

Among genes belonging to "AhR signaling", we recently reported the regulation of CYP1A1, CYP1B1 and the cyclin-dependent kinase inhibitor 1A (CDKN1A) in human T lymphocytes upon exposure to $\mathrm{B}[\alpha] \mathrm{P}[16]$. The AhR repressor $(A h R R)$, the cyclin E2 (CCNE2) and the NAD(P)H dehydrogenase (NQO1) have already been reported to be robust targets of $\mathrm{B}[\alpha] \mathrm{P}$ but, in different cell types, but not in primary T lymphocytes $[19,20]$. We then validated by RT-qPCR assays these changes in $A h R R, C C N E 2, C D K N 1 A, C Y P 1 A 1, C Y P 1 B 1$, and NQO1 gene expression changes using the 16 individual RNA samples isolated from CTR and B $[\alpha]$ P-treated T lymphocyte cultures (Figure $3 \mathrm{~A}$ ). Interestingly, "IFN signaling" and "activation of IRF by cytosolic pattern recognition receptors" pathways were found to be closely associated with genes exhibiting a significant down-regulation in human T lymphocytes treated with $\mathrm{B}[\alpha] \mathrm{P}$ (Table 2). RT-qPCR analysis further validated the gene expression down-regulations of IFIT3, MX1, OAS1 expressions (all related to "IFN signaling") and of the RNA helicase (DDX58), the IFN-induced protein with helicase C domain (IFIH1) and IFIT2 (all belonging to "activation of IRF by cytosolic pattern recognition receptors") (Figure 3B), using the same 16 RNA samples as for AhR signaling-related genes (Figure 3B). Such an analysis identifies these IFN-related proteins as novel target genes for $\mathrm{B}[\alpha] \mathrm{P}$. 


\section{A}

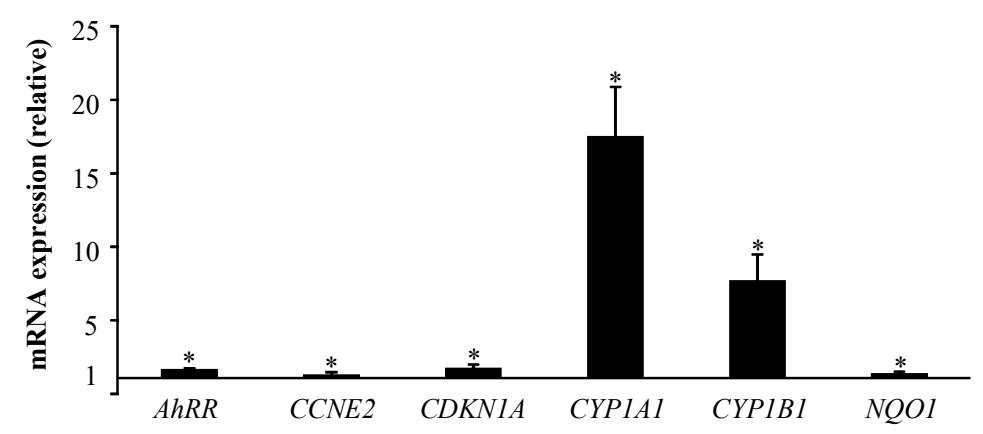

B

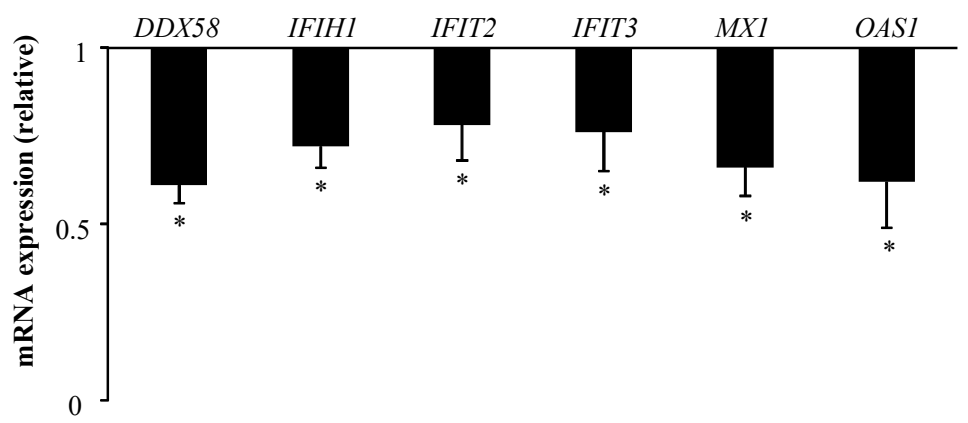

Figure 3. Validation by RT-qPCR analysis of AhR (A) and IFN (B) signaling-related genes identified by microarray experiments after treatment of human T lymphocytes with $2 \mu \mathrm{M} \mathrm{B}[\alpha] \mathrm{P}$ for $48 \mathrm{~h}$. Primary human $\mathrm{T}$ lymphocytes activated for $72 \mathrm{~h}$ were treated with DMSO (CTR) or with $2 \mu \mathrm{M} \mathrm{B}[\alpha] \mathrm{P}$ for the last $48 \mathrm{~h}$ of culture. mRNA expression was analyzed using RT-qPCR. Data are expressed relative to mRNA expression level in CTR T lymphocytes, arbitrarily set at 1 unit, and are shown as mean \pm SEM of 16 independent experiments performed on the individual RNAs isolated from CTR or B $[\alpha]$-treated cultures, with triplicate per experiment. ${ }^{*} p \leq 0.05$ when compared with CTR T lymphocytes (paired Student's $t$ test).

\subsection{IPA Functional Analysis Revealed the Prominence of Categories Related to Cellular Movement for $B[\alpha] P$-Regulated Genes in Human T Lymphocytes}

With the aim of better understanding the biological relevance of the changes in the expression of 158 genes upon $\mathrm{B}[\alpha] \mathrm{P}$ exposure, IPA software was used to analyze the most significant diseases and disordered biological functions regulated in $\mathrm{T}$ lymphocytes after $\mathrm{B}[\alpha] \mathrm{P}$ exposure. As shown in Table 3, the five most significant diseases and disorders revealed by such an analysis were cancer, haematological disease, immunological disease, organismal injury and abnormalities, and antimicrobial response. Cellular movement, cell death and survival, cellular function and maintenance, cell-to-cell signaling and interaction and cellular growth and proliferation were the top five significant molecular and cellular functional categories found to be altered in human $\mathrm{T}$ lymphocytes after a $48 \mathrm{~h}$ treatment with $\mathrm{B}[\alpha] \mathrm{P}$ (Table 3). Immune cell trafficking, hematological system development and function, tissue morphology, digestive system development and function and lymphoid tissue structure and development were the five most significant categories in physiological development and system function associated with $\mathrm{B}[\alpha] \mathrm{P}$-modulated genes in T lymphocytes (Table 3 ). 
Table 3. Top diseases and biological functions regulated after treatment of human T lymphocytes with $2 \mu \mathrm{M} \mathrm{B}[\alpha] \mathrm{P}$ for $48 \mathrm{~h}$.

\begin{tabular}{|c|c|c|c|}
\hline Network & Top Functions & $p$-Value ${ }^{\text {a }}$ & Focus Genes ${ }^{b}$ \\
\hline \multicolumn{4}{|c|}{ Diseases and Disorders } \\
\hline 1 & Cancer & $1.82 \times 10^{-3}-1.61 \times 10^{-12}$ & 144 \\
\hline 2 & Hematological Disease & $1.64 \times 10^{-3}-1.61 \times 10^{-12}$ & 67 \\
\hline 3 & Immunological Disease & $1.64 \times 10^{-3}-1.61 \times 10^{-12}$ & 73 \\
\hline 4 & Organismal Injury and Abnormalities & $1.82 \times 10^{-3}-1.61 \times 10^{-12}$ & 147 \\
\hline 5 & Antimicrobial Response & $2.89 \times 10^{-4}-2.23 \times 10^{-10}$ & 19 \\
\hline \multicolumn{4}{|c|}{ Molecular and Cellular functions } \\
\hline 1 & Cellular Movement & $1.77 \times 10^{-3}-6.81 \times 10^{-12}$ & 60 \\
\hline 2 & Cell Death and Survival & $1.59 \times 10^{-3}-2.05 \times 10^{-11}$ & 77 \\
\hline 3 & Cellular Function and Maintenance & $1.30 \times 10^{-3}-7.97 \times 10^{-11}$ & 52 \\
\hline 4 & Cell-To-Cell Signaling and Interaction & $1.82 \times 10^{-3}-4.36 \times 10^{-8}$ & 41 \\
\hline 5 & Cellular Growth and Proliferation & $1.68 \times 10^{-3}-5.20 \times 10^{-8}$ & 77 \\
\hline \multicolumn{4}{|c|}{ Physiological system development and function } \\
\hline 1 & Immune Cell Trafficking & $1.82 \times 10^{-3}-6.81 \times 10^{-12}$ & 45 \\
\hline 2 & Hematological System Development and Function & $1.82 \times 10^{-3}-5.20 \times 10^{-10}$ & 64 \\
\hline 3 & Tissue Morphology & $1.67 \times 10^{-3}-2.55 \times 10^{-9}$ & 56 \\
\hline 4 & Digestive System Development and Function & $1.07 \times 10^{-3}-1.75 \times 10^{-7}$ & 25 \\
\hline 5 & Lymphoid Tissue Structure and Development & $1.78 \times 10^{-3}-1.75 \times 10^{-7}$ & 48 \\
\hline
\end{tabular}

Interestingly, these IPA functional data revealed the prominence of categories related to lymphocyte movement for $\mathrm{B}[\alpha] \mathrm{P}$-regulated genes. Based on that, we then decided to focus on gene sets linked to this function. Consistent with our transcriptomic data, and using RT-qPCR on the same pools of RNA as those used in microarray experiments, mRNA expressions of the surface receptors CD226, CXCR5, GPR15, and S1PR1, the interleukin IL-22, the plasma-membrane-associated class I myosin $M Y O 1 G, N Q O 1$, and the membrane-bound guanine nucleotide binding protein SOS1 were found to be significantly up-regulated after exposure to $\mathrm{B}[\alpha] \mathrm{P}$ (Figure $4 \mathrm{~A}$ ). We also confirmed the decreased mRNA expressions of the annexin A1 (ANXA1), the chemokines (C-C motif) ligands CCL3, CCL3L3, DDX58, the membrane dipeptidyl peptidase 4 (DPP4), the interleukin 7 receptor (IL7R), the oncostatin $\mathrm{M}(\mathrm{OSM})$ and the leukocyte-endothelial cell adhesion molecule (SELL), with all of these repressions reaching a significant level, except for ANXA1 (Figure 4B). 

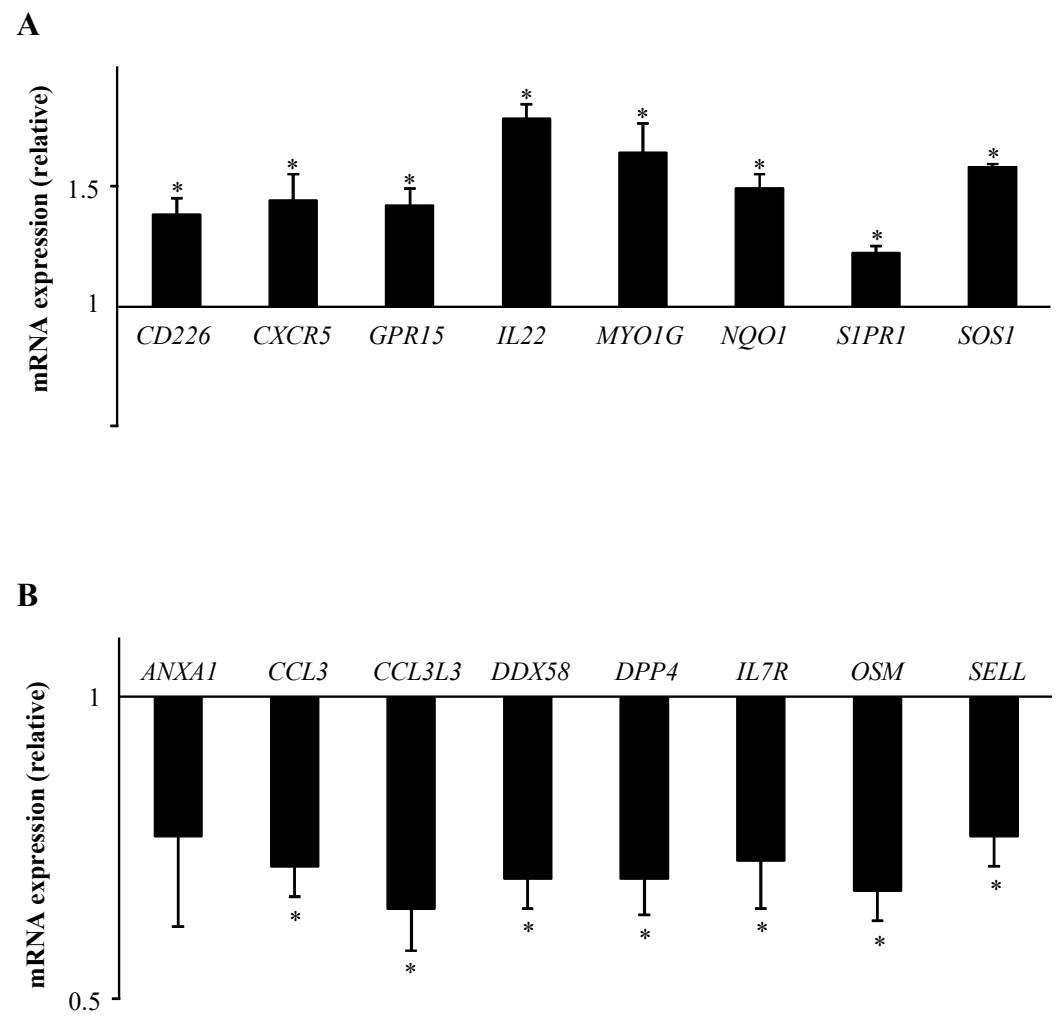

Figure 4. Validation by RT-qPCR analysis of cellular movement-related genes identified by microarray experiments after treatment of human T lymphocytes with $2 \mu \mathrm{M} \mathrm{B}[\alpha] \mathrm{P}$ for $48 \mathrm{~h}$. Primary human $\mathrm{T}$ lymphocytes activated for $72 \mathrm{~h}$ were treated with DMSO (CTR) or with $2 \mu \mathrm{M} \mathrm{B}[\alpha] \mathrm{P}$ for the last $48 \mathrm{~h}$ of culture. mRNA expression was analyzed using RT-qPCR. Data are expressed relative to mRNA expression level in CTR T lymphocytes, arbitrarily set at 1 unit, and are shown as mean \pm SEM of 4 independent experiments performed on the same pools of RNAs isolated from CTR or B $[a] \mathrm{P}$-treated cultures as those used in microarray experiments, with triplicate per experiment. ${ }^{*} p \leq 0.05$ when compared with CTR T lymphocytes (paired Student's $t$ test).

\subsection{B[a]P Inhibits Human T Lymphocyte Chemotaxis and Transendothelial Migration}

Based on its effects on the mRNA expression of genes that are known to be related to lymphocyte movement, $\mathrm{B}[\alpha] \mathrm{P}$ was thus identified as a potential modulator of $\mathrm{T}$ lymphocyte recruitment. To gain insight into this role of $\mathrm{B}[\alpha] \mathrm{P}$, we first used the 16 individual RNA samples isolated from CTR and $\mathrm{B}[\alpha] \mathrm{P}$-treated $\mathrm{T}$ lymphocytes to validate the unexpected regulation of specific genes linked to $\mathrm{T}$ cell homing and trafficking, i.e., CCL3, CCL3L3, DPP4, GPR15, OSM, S1PR1 and SELL. As shown in Figure 5A, mRNA expressions of GPR15 and S1PR1 were significantly up-regulated, whereas those of CCL3, CCL3L3, DPP4, OSM and SELL were down-regulated in human T lymphocytes after a 48-h treatment with $\mathrm{B}[\alpha] \mathrm{P}$. These genes therefore represent novel target genes for $\mathrm{B}[\alpha] \mathrm{P}$, and highlight the possible interplay between $\mathrm{B}[\alpha] \mathrm{P}$ exposure and altered $\mathrm{T}$ lymphocyte recruitment. This next prompted us to further explore the effect of $\mathrm{B}[\alpha] \mathrm{P}$ on the migration of primary human $\mathrm{T}$ lymphocytes by performing functional experiments. The molecular processes involved in $\mathrm{T}$ lymphocyte migration are not only chemotaxis, mainly mediated by chemokines/cytokines, but also cellular adhesion, involving selectins or surface receptors [21]. We first developed a transwell assay to investigate the possible regulation of $\mathrm{T}$ lymphocytes chemotaxis by $\mathrm{B}[\alpha] \mathrm{P}$. To do so, we used a gelatin-precoated $8 \mu \mathrm{m}$ pore cell culture insert in which primary human T lymphocytes, treated or not with $\mathrm{B}[\alpha] \mathrm{P}$, were allowed to migrate to the basolateral compartment of the transwell system either containing or not containing CXCL12, an highly efficient chemoattractant for T lymphocytes classically used in chemotaxis assays [22]. As shown in Figure 5B, CXCL12 clearly increased the percentage of migrated $\mathrm{T}$ lymphocytes, confirming the response of $\mathrm{T}$ lymphocytes to this cytokine, and $\mathrm{B}[\alpha] \mathrm{P}$ significantly 
inhibited this CXCL12-induced chemotaxis. We next developed another transwell assay to evaluate $\mathrm{T}$ lymphocyte migration through the blood vessel wall. Therefore, we compared the ability of CTR and $\mathrm{B}[\alpha]$ P-treated T lymphocytes to migrate across Tumor Necrosis Factor- $\alpha$-stimulated HMEC- 1 in response or not to CXCL12, which also plays an important role in the transendothelial migration of $\mathrm{T}$ cells in response to immune processes [23]. Interestingly, $\mathrm{B}[\alpha] \mathrm{P}$ decreased $\mathrm{T}$ lymphocyte migration across membrane coated with activated endothelial cells, with a significant inhibition in response to CXCL12 (Figure 5C). Altogether, these data indicate that $\mathrm{B}[\alpha] \mathrm{P}$ cause a significant inhibition of the CXCL12-induced chemotaxis and transendothelial migration of $\mathrm{T}$ lymphocytes, therefore identifying a novel immunotoxic effect of this contaminant.

$\mathbf{A}$

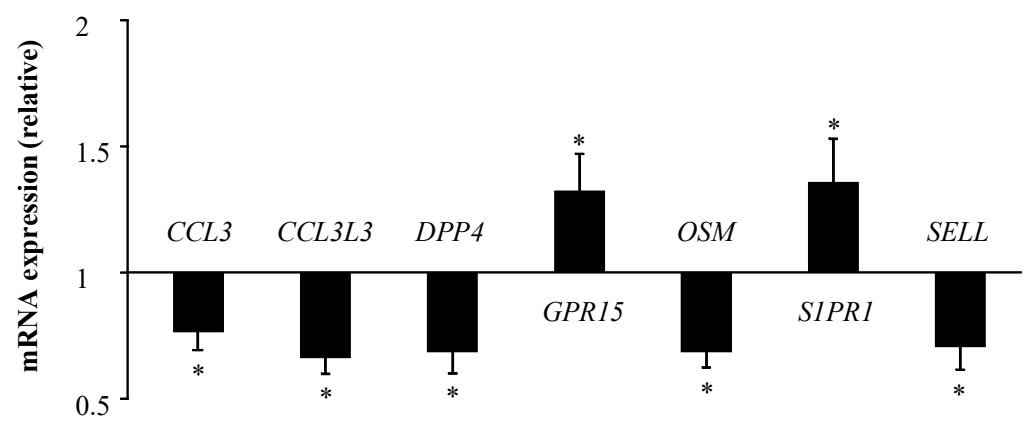

B

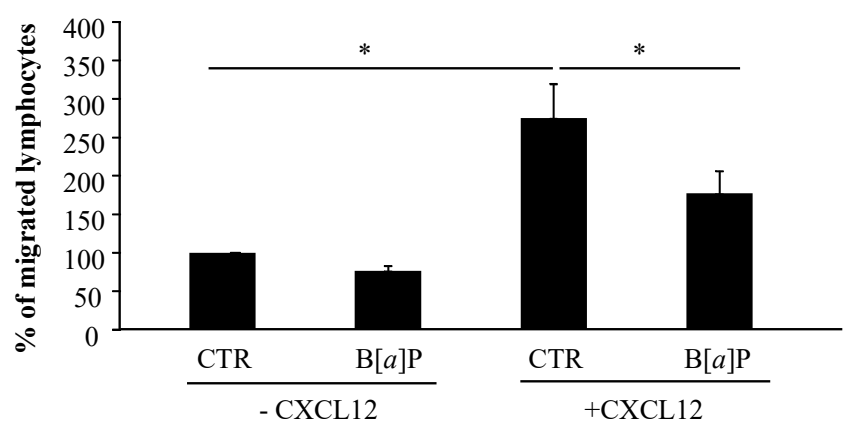

C

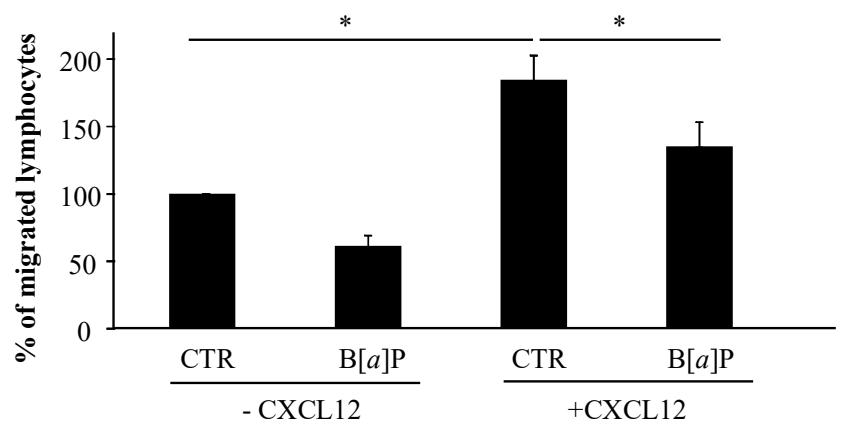

Figure 5. Effect of $\mathrm{B}[\alpha] \mathrm{P}$ on chemotaxis and endothelial transmigration of human $\mathrm{T}$ lymphocytes. Primary human T lymphocytes activated for $72 \mathrm{~h}$ were treated with DMSO (CTR) or with $2 \mu \mathrm{M} \mathrm{B}[\alpha] \mathrm{P}$ for the last $48 \mathrm{~h}$ of culture. (A) mRNA expression was analyzed using RT-qPCR. Data are expressed relative to mRNA expression level in CTR T lymphocytes, arbitrarily set at 1 unit, and are shown as mean \pm SEM of 16 independent experiments performed on the individual RNAs isolated from CTR or $\mathrm{B}[\alpha]$ P-treated cultures, with triplicate per experiment. ${ }^{*} p \leq 0.05$ when compared with CTR T lymphocytes (paired Student's $t$ test). (B, C) T lymphocytes were then used for chemotaxis (B) and transendothelial migration (C) assays with or without CXCL12. Data are expressed as percentages of migrated lymphocytes found in CTR T lymphocytes without CXCL12, and are shown as means \pm SEM of 6 independent experiments with duplicate per experiment. ${ }^{*} p \leq 0.05$ when compared with CTR T lymphocytes (analysis of variance followed by Student-Newman-Keuls's multirange test). 


\section{Discussion}

The aim of the present study was to characterize the global transcriptional response of human $\mathrm{T}$ lymphocytes to $\mathrm{B}[\alpha] \mathrm{P}$. To the best of our knowledge, this study provides the first insight into the global transcriptional activity that underlies the effects of $\mathrm{B}[\alpha] \mathrm{P}$ in activated primary human $\mathrm{T}$ lymphocytes, a relevant model for human health issues. Indeed, we previously reported that physiological activation of human T lymphocytes by anti-CD3 and anti-CD28 antibodies is of great interest towards the exposure to PAHs, such as $\mathrm{B}[\alpha] \mathrm{P}[7,16]$, thus supporting their genotoxic effects and reinforcing the link suggested between PAH exposure and risk of T lymphoma [24]. However, in this model, the immunotoxic effects of PAHs remain incompletely characterized. Our microarray data indicated that a 48-h treatment of primary human $\mathrm{T}$ lymphocytes with $\mathrm{B}[\alpha] \mathrm{P}$ resulted in 158 significantly regulated genes. This represents around $1 \%$ of the analyzed genes but we cannot exclude the possibility that other treatment conditions in terms of timing might result in an amplified effect in T lymphocytes. Interestingly, gene expression has been previously reported to be tightly regulated in activated human T lymphocytes through rapid mRNA decay as a part of an homeostatic mechanism to down-modulate an immune response, thus reflecting transient responses in this model [25]. Additionally, except for the AhR target genes, CYP1A1 and CYP1B1 [4], few of the 158 differentially expressed transcripts displayed strong amplitude in the changes observed. Compression of level expression in microarray has already been reported [26], and could be due to stringent normalization conditions. Nevertheless, validation by RT-qPCR assays showed that a large number of the 158 regulated transcripts identified by our microarray experiments was confirmed to be differentially expressed in human $\mathrm{T}$ lymphocytes after $\mathrm{B}[\alpha] \mathrm{P}$ treatment, therefore demonstrating the global robustness of this transcriptomic analysis.

Among genes identified by our study, some have already been described to be targeted by $\mathrm{B}[\alpha] \mathrm{P}$. This is notably true for CYP1A1, CYP1B1, the ferredoxin reductase (FDXR), NQO1, CDKN1A, AhRR, ASB2 or TIPARP up-regulated genes [17-19,27,28] and $M X 1$ or the solute carrier SLC25A37, regarding the down-regulated ones $[29,30]$. All these genes therefore appear as robust PAH targets. Many target genes reported in the present work have never been identified as $\mathrm{B}[\alpha] \mathrm{P}$ targets in previous studies investigating its transcriptional signature. Our study allows us to identify novel $\mathrm{B}[\alpha] \mathrm{P}$ target genes such as the connexins GJB2, GJB6, and the IFN-induced proteins IFI44L, IFI44, IFIH1, IFIT2 or IFIT3. These identifications likely support the concept of a cell-specific genomic response to PAHs, therefore discarding the idea of a universal battery of AhR-responsive genes as already reported [31]. In further support to that concept, we previously analyzed the transcriptional signature of human macrophages exposed to $\mathrm{B}[\alpha] \mathrm{P}[18]$, and found that the degree of overlap between $\mathrm{B}[\alpha] \mathrm{P}$-induced expression profiles of macrophages and T lymphocytes was surprisingly small. Nevertheless, AhR- and p53-target genes such as CYP1A1, CYP1B1, AhRR, ASB2 or CDKN1A and the ribonucleotide reductase $R R M 2 B$ were shown to be modulated in both type of cells, all encoding enzymes important in the detoxication and the DNA damage response induced after $\mathrm{B}[\alpha] \mathrm{P}$ exposure $[16,18]$.

Beyond the identification of individual genes, our analysis also focused on the identification and characterization of pathways and functions altered after $\mathrm{B}[\alpha] \mathrm{P}$ treatment of human $\mathrm{T}$ lymphocytes. AhR signaling is the most significant canonical pathway activated by a 48-h exposure to $2 \mu \mathrm{M}$ $\mathrm{B}[\alpha] \mathrm{P}$. This finding is not surprising since $\mathrm{B}[\alpha] \mathrm{P}$ is well-known to act as a potent ligand of $\mathrm{AhR}[4]$ and indicate that a notable number of genes induced by $\mathrm{B}[\alpha] \mathrm{P}$ in human $\mathrm{T}$ lymphocytes is under the control of AhR. However, since AhR has the ability to act not only as a transcription factor, but also as a signaling mediator [32], the dependence on AhR genomic or non-genomic signaling remains to be elucidated. Regarding the down-regulated genes, prominence of the IFN signaling pathway for enrichment was surprising. IFNs are cytokines exhibiting important roles in the immune response to confer an antiviral state in cells on viral infection [33]. Interestingly, constitutive AhR signaling leading to TIPARP up-regulated expression has previously been shown to negatively regulate the type I IFN response during infections with various types of virus in mice [34]. More recently, Guan et al. [35] reported a suppression of IFN- $\gamma$ production by B $\alpha] \mathrm{P}$ in activated mouse T lymphocytes, which contribute to its immunotoxic effects. In the present study, we propose a link between 
PAH exposure and down-regulation of the IFN response in human T lymphocytes, which might potentially explain the increased incidence of respiratory viral infections after exposure to these environmental air pollutants [36]. In addition, and with respect to the biological functions altered by $\mathrm{B}[\alpha] \mathrm{P}$, processes related to $\mathrm{T}$ lymphocyte recruitment appear as the most affected, leading us to propose $\mathrm{B}[\alpha] \mathrm{P}$ as a modulator of $\mathrm{T}$ cell migration. Indeed, the identification, as novel $\mathrm{B}[\alpha] \mathrm{P}$ targets, of chemokines/cytokines such as CCL3, CCL3L3 or OSM, and of the surface receptors like DPP4, GPR15, S1PR1 and SELL, underlines the link previously suggested in the human T-lymphoid cell line Jurkat [37] between $\mathrm{B}[\alpha] \mathrm{P}$ exposure and lymphocyte recruitment. Among these genes, CCL3, CCL3L3, DPP4, OSM and SELL are down-regulated by $\mathrm{B}[\alpha]$ P. Interestingly, CCL3 is a chemokine that not only mediates immune cell chemotaxis, but also regulates $\mathrm{T}$ lymphocyte function and migration following viral infection [38]; the cytokine OSM has been proposed to control the emigration of lymphocytes through a sustained expression of selectin [39], and the homing receptor SELL appears crucial for T lymphocyte activation and migration from lymph nodes, as reported in lymphoma [40]. In agreement with these down-regulated expressions, the data reported in the present study indicate that $\mathrm{B}[\alpha] \mathrm{P}$ significantly inhibited migration of human $\mathrm{T}$ lymphocytes towards CXCL12 gradients. This emerging role of $\mathrm{B}[\alpha] \mathrm{P}$ as an inhibitor of T lymphocyte responsiveness to CXCL12 could also be postulated as a novel immunosuppressive effect of $\mathrm{B}[\alpha] \mathrm{P}$ leading to the increased susceptibility to infections upon exposure to environmental air pollutants [36]. However, the molecular mechanism by which $\mathrm{B}[\alpha] \mathrm{P}$ reduces the CXCL12-induced chemotaxis and migration of T lymphocytes, remains to be elucidated. As classically reported for B $[\alpha]$ P-induced immunosuppressive effects $[12,18]$, AhR and CYP1-dependent metabolism might play a major role in these inhibitory effects. Nevertheless, a down-regulated expression of proteins involved in T lymphocyte motility by $\mathrm{B}[\alpha] \mathrm{P}[37]$, as well as an inhibition of migration in response to CXCL12 by another AhR ligand, the flavonoid genistein [41], have been reported in Jurkat cells showing no detectable $\mathrm{AhR}$ and $\mathrm{B}[\alpha] \mathrm{P}$ metabolites [42], thus suggesting that AhR activation and mechanisms-unrelated to $\mathrm{B}[\alpha] \mathrm{P}$ metabolism may account for these inhibitory effects towards migration. In addition, since IFN has been shown to play a critical role in T lymphocyte recruitment $[43,44]$, it will also be interesting to further explore the role of IFN signaling in this decreased T lymphocyte migration.

Besides the interest in better understanding molecular bases of PAH toxicity, the identification of new $\mathrm{B}[\alpha] \mathrm{P}$-target genes in lymphocytes also provides potential new biomarkers of exposure to PAHs, which may be convenient for biomonitoring exposed subjects. In addition, it should be kept in mind that most of the microarray-based transcriptomic analysis of gene expression changes due to PAHs have been performed using human transformed cell lines or rodent cells $[17,27,45]$. This therefore opens the question of the relevance of the data obtained in those studies to human. Data obtained with primary human lymphocytes, which are normal non-transformed human cells, may be consequently more adequate to better characterize the response of normal human cells/tissues to environmental contaminants such as $\mathrm{B}[\alpha] \mathrm{P}$. More detailed studies are needed to clarify the potential of these genes as new biomarkers of exposure to PAHs.

Together these results identified lymphocytic genes whose expression was targeted by $\mathrm{B}[\alpha] \mathrm{P}$. Analysis of these data indicated that AhR and IFN signaling cascades constitute major canonical pathways activated by $\mathrm{B}[\alpha] \mathrm{P}$, whereas biological functions linked to T lymphocyte recruitment are among the most affected, thus reinforcing the immunotoxic effects of PAHs.

\section{Materials and Methods}

\subsection{Cell Culture and Treatment}

Peripheral blood mononuclear cells were isolated from blood donor buffy coats (written consent for the use of blood samples for the research protocol obtained according to the regulation for blood transfusion of the French blood organization Etablissement Français du Sang, Rennes (France)) by Ficoll (Thermofischer Scientific, Braunschweig, Germany) gradient centrifugation. After separation of monocytes by a 1-h adhesion step, $\mathrm{T}$ lymphocytes were purified from nonadherent 
cells by negative selection using Dynabeads ${ }^{\circledR}$ Untouched $^{\mathrm{TM}}$ Human T Cells Kit (Thermofischer Scientific). T lymphocytes were cultured in RPMI medium (Eurobio, Les Ulis, France) supplemented with $20 \mathrm{IU} / \mathrm{mL}$ penicillin, $20 \mu \mathrm{g} / \mathrm{mL}$ streptomycin, and $10 \%$ decomplemented fetal calf serum (Thermofischer Scientific), and stimulated with Dynabeads ${ }^{\circledR}$ T-Expander beads coated with anti-CD3 and anti-CD28 antibodies (Thermofischer Scientific) before a 48-h treatment with $2 \mu \mathrm{M} \mathrm{B}[\alpha] \mathrm{P}$ (Sigma-Aldrich, St. Louis, MO, USA) as previously reported [16]. B $[\alpha] \mathrm{P}$ was used as stock solutions in dimethylsulfoxide (DMSO). The final concentration of DMSO in culture medium was always $<0.2 \%$ $v / v$ and control cultures received a vehicle containing the same concentration of DMSO (CTR) as treated cultures.

\subsection{Microarray Experiments}

\subsubsection{RNA Extraction}

Total RNA was isolated from T lymphocytes using the TRIzol method (Thermofischer Scientific) and then purified using a RNeasy Mini Kit with on-column RNAse-free DNAse digestion (Qiagen, Courtaboeuf, France), according to the manufacturer's protocol. RNA was next quantified with the nanodrop ND-1000 spectrophotometer (Nano-Drop Technologies, Rockland, DE, USA), and RNA integrity was assessed with RNA 6000 Nano LabChip kit using the Agilent 2100 Bioanalyzer (Agilent Technologies, Palo Alto, CA, USA). Only RNA with an RNA integrity number $>9$ was used for further analysis (2100 expert software, Agilent Technologies). Independent $\mathrm{T}$ lymphocyte cultures isolated from 16 blood donors, each available in CTR and $\mathrm{B}[\alpha]$ P-treated conditions were performed. Equal amounts of RNAs were pooled from these cultures to constitute 4 equimolar pools with 4 different blood donors per pool. Pooling small samples for array analysis is considered advantageous in situations where the level of biological variation could be high compared to technical variation on the array $[18,46]$.

\subsubsection{Microarray Hybridization}

Total RNA was amplified and labelled using the Gene Chip ${ }^{\mathrm{TM}}$ WT PLUS Reagent Kit according to the manufacturer's instructions (ThermoFischer Scientific). For each sample, RNA pools were hybridized to Human Clariom ${ }^{\mathrm{TM}} \mathrm{S}$ GeneChip (ThermoFischer Scientific). Arrays were immediately scanned, and images were analyzed and rigorously quality controlled for hybridization artefacts.

\subsubsection{Data Normalization}

The resulting CEL files were processed using the oligo package available performed in R/Bioconductor [47]. Data were then normalized and background corrected using the SCAN.UPC package [48] with the Brainarray custom CDF file for directly mapping Affymetrix probe to Entrez gene identifiers (hta20_Hs_ENTREZG version 21.0.0) [49]. Data were uploaded to the NCBI Gene Expression Omnibus (GEO) repository under the accession number GSE117527 [50]. Lists of genes significantly induced or repressed after $\mathrm{B}[\alpha] \mathrm{P}$ exposure were also uploaded to the TOXsIgN repository under the accession TSP758 [51].

\subsection{Statistical Filtration of Differentially Expressed Genes}

The statistical filtration of the genes differentially expressed between CTR and B $[\alpha]$ P-treated samples was performed using the Annotation, Mapping, Expression and Network suite of tools [52]. Briefly, we first filtered genes with at least one signal above the background expression cutoff $(\geq 0.0)$ and with a minimal variation of $10 \%$ between both experimental conditions as determined by the inflection point of the fold-change curve (Supplementary Figure S1). Finally, a paired Student's $t$ test $(p \leq 0.05)$ was used to identify significantly differentially expressed genes which were further classified into two expression patterns: Up-regulated and down-regulated genes after $\mathrm{B}[\alpha] \mathrm{P}$ exposure. 


\subsection{Functional Analysis by Ingenuity Pathway Analysis (IPA)}

Lists of genes significantly induced or repressed after $\mathrm{B}[\alpha] \mathrm{P}$ exposure were uploaded into IPA software (IPA, Ingenuity Systems, QIAGEN, available online: www.ingenuity.com) for signaling pathways and biological functions analysis by comparison with the Ingenuity Knowledge Database.

\section{5. $R T-q P C R$ Assays}

Total RNA was isolated from the same independent $\mathrm{T}$ lymphocyte cultures isolated from 16 blood donors as used for microarray experiments using the TRIzol method (Thermofischer Scientific) and then reverse-transcribed into cDNA using the RT Applied Biosystems kit (Foster City, CA, USA). qPCR assays were performed using gene-specific primers from Eurogentec (Seraing, Belgium). The amplification curves of the PCR products were analyzed with the ABI Prism SDS software using the comparative cycle threshold method. Relative quantification of the steady-state target mRNA levels was calculated after normalization of the total amount of cDNA tested to a 18S mRNA endogenous reference as previously described [16].

\subsection{Chemotaxis and Transendothelial Migration Assays}

Chemotaxis assays were carried out using 24-well transwell chambers exhibiting $8 \mu \mathrm{m}$ pores (Dutscher, Brumath, France). Into each transwell pre-coated with $0.1 \%$ gelatin, $5 \times 10^{5} \mathrm{~T}$ lymphocytes in $200 \mu \mathrm{L}$ were transferred. The transwell was then inserted into a 24-well plate containing a $0.6 \mathrm{~mL}$ volume of the chemotaxis medium (RPMI, $1 \%$ bovine serum albumine, $2 \%$ fetal calf serum) with or without the chemokine (C-X-C motif) ligand 12 (CXCL12) $(50 \mathrm{ng} / \mathrm{mL})$ (Preprotech, Rocky Hill, USA). Migration was allowed for $3 \mathrm{~h}$ at $37^{\circ} \mathrm{C}$. Lymphocytes which migrated across the membrane were harvested and subsequently counted by Malassez counting slide. For each experiment migration, data have been normalized considering the number of counted cells in CTR conditions as $100 \%$.

For transmigration assays through an endothelial monolayer, 200,000 human immortalized microvascular endothelial cells (HMEC-1) $/ \mathrm{cm}^{2}$ were seeded onto a $0.1 \%$ gelatin pre-coated transwell and allowed to form a complete monolayer on the membrane of $8 \mu \mathrm{m}$ pore size 24-well transwell in MCDB-131 medium containing epidermal growth factor $(10 \mathrm{ng} / \mathrm{mL})$, hydrocortisone $(1 \mu \mathrm{g} / \mathrm{mL})$, glutamine $(10 \mathrm{mM})$ (Thermofischer Scientific), penicillin $(50$ units $/ \mathrm{mL})$ and streptomycin $(50 \mu \mathrm{g} / \mathrm{mL})$ and supplemented with $10 \%$ fetal calf serum as previously reported [53]. HMEC-1 barrier was controlled by measuring transendothelial electrical resistance using the Millicell ERS- $2^{\circledR}$ (Merck Millipore, Darmstadt, Germany). HMEC-1 were then activated using Tumor Necrosis Factor- $\alpha$ (Thermofischer Scientific) $\left(10 \mathrm{ng} / \mathrm{mL}\right.$ ) for $8 \mathrm{~h}$. Into each transwell, $5 \times 10^{5} \mathrm{~T}$ lymphocytes in $200 \mu \mathrm{L}$ were transferred and the transwell was inserted into a 24-well plate containing a chemotaxis medium with or without CXCL12 as previously reported for chemotaxis assays. Migration was allowed for $3 \mathrm{~h}$ at $37^{\circ} \mathrm{C}$ and the number of migrated lymphocytes was evaluated, as described above.

\subsection{Statistical Analysis}

Data are expressed as means \pm SEM. Statistical significance of the differences was assessed using GraphPad Instat (GraphPad software, INC., La Jolla, CA, USA) by paired Student's $t$ test or one-way analysis of variance followed by Student-Newman-Keuls post hoc tests. The criterion of significance was $p \leq 0.05$.

Supplementary Materials: Supplementary materials can be found at http:/ /www.mdpi.com/1422-0067/19/11/ $3626 /$ s1. Table S1: Genes differentially regulated after treatment of human T lymphocytes with $2 \mu \mathrm{M} \mathrm{B}[\alpha] \mathrm{P}$ for 48 h. Figure S1: Selection criteria for microarray data. 
Author Contributions: Conceptualization, F.C., E.B.-R., E.L.F. and L.S.; Data curation, L.H., F.C., E.B.-R. and L.S.; Formal analysis, M.L., H.L.M., B.E., L.H., F.C., E.B.-R., E.L.F. and L.S.; Funding acquisition, L.S.; Investigation, M.L., H.L.M., B.E. and E.L.F.; Methodology, M.L., H.L.M., B.E., L.H., F.C., E.B.-R., E.L.F. and L.S.; Project administration, L.S.; Resources, L.H., F.C., E.B.-R., E.L.F. and L.S.P.; Software, L.H., F.C., E.B.-R. and L.S.; Supervision, L.S.; Validation, M.L., H.L.M. and B.E.; Visualization, M.L. and L.S.; Writing-original draft, L.S.; Writing一review \& editing, M.L., L.H., F.C., E.B.-R. and E.L.F.

Acknowledgments: This work was supported by The French National Research Program for Environmental and Occupational Health of ANSES with the support of the Cancer TMOI of the French National Alliance for Life and Health Sciences (AVIESAN) [2014/1/052]. Marie Liamin is a recipient of ANSES. We would like to thank Dr Lagadic-Gossmann for thorough reading of our manuscript.

Conflicts of Interest: The authors declare no conflict of interest.

\section{References}

1. Hattemer-Frey, H.A.; Travis, C.C. Benzo-a-pyrene: Environmental partitioning and human exposure. Toxicol. Ind. Health 1991, 7, 141-157. [CrossRef] [PubMed]

2. Clark, J.D.; Serdar, B.; Lee, D.J.; Arheart, K.; Wilkinson, J.D.; Fleming, L.E. Exposure to polycyclic aromatic hydrocarbons and serum inflammatory markers of cardiovascular disease. Environ. Res. 2012, 117, $132-137$. [CrossRef] [PubMed]

3. Rubin, H. Synergistic mechanisms in carcinogenesis by polycyclic aromatic hydrocarbons and by tobacco smoke: A bio-historical perspective with updates. Carcinogenesis 2001, 22, 1903-1930. [CrossRef] [PubMed]

4. Hankinson, O. The aryl hydrocarbon receptor complex. Annu. Rev. Pharmacol. Toxicol. 1995, 35, 307-340. [CrossRef] [PubMed]

5. De Vries, A.; Dollé, M.E.; Broekhof, J.L.; Muller, J.J.; Kroese, E.D.; van Kreijl, C.F.; Capel, P.J.; Vijg, J.; van Steeg, H. Induction of DNA adducts and mutations in spleen, liver and lung of XPA-deficient/lacZ transgenic mice after oral treatment with benzo[a]pyrene: Correlation with tumour development. Carcinogenesis 1997, 18, 2327-2332. [CrossRef] [PubMed]

6. Okano, P.; Miller, H.N.; Robinson, R.C.; Gelboin, H.V. Comparison of benzo(a)pyrene and (-)-trans-7,8-dihydroxy-7,8-dihydrobenzo(a)pyrene metabolism in human blood monocytes and lymphocytes. Cancer Res. 1979, 39, 3184-3193. [PubMed]

7. Prigent, L.; Robineau, M.; Jouneau, S.; Morzadec, C.; Louarn, L.; Vernhet, L.; Fardel, O.; Sparfel, L. The aryl hydrocarbon receptor is functionally upregulated early in the course of human T-cell activation. Eur. J. Immunol. 2014, 44, 1330-1340. [CrossRef] [PubMed]

8. White, K.L.; Lysy, H.H.; Holsapple, M.P. Immunosuppression by polycyclic aromatic hydrocarbons: A structure-activity relationship in B6C3F1 and DBA/2 mice. Immunopharmacology 1985, 9, 155-164. [CrossRef]

9. Wojdani, A.; Alfred, L.J. Alterations in cell-mediated immune functions induced in mouse splenic lymphocytes by polycyclic aromatic hydrocarbons. Cancer Res. 1984, 44, 942-945. [PubMed]

10. Selgrade, M.J.; Daniels, M.J.; Burleson, G.R.; Lauer, L.D.; Dean, J.H. Effects of 7,12-dimethylbenz[a]anthracene, benzo[a]pyrene and cyclosporin A on murine cytomegalovirus infection: Studies of resistance mechanisms. Int. J. Immunopharmacol. 1988, 10, 811-818. [CrossRef]

11. Dean, J.H.; Luster, M.I.; Boorman, G.A.; Lauer, L.D.; Ward, E.C. Immunotoxicity of Tumor Promoting Environmental Chemicals and Phorbol Diesters. In Advances in Immunopharmacology; Hadden, J.W., Chedid, L., Dukor, P., Spreafico, F., Willoughby, D., Eds.; Pergamon: Amsterdam, The Netherlands, 1983; ISBN 978-0-08-029775-0.

12. Davila, D.R.; Romero, D.L.; Burchiel, S.W. Human T cells are highly sensitive to suppression of mitogenesis by polycyclic aromatic hydrocarbons and this effect is differentially reversed by $\alpha$-naphthoflavone. Toxicol. Appl. Pharmacol. 1996, 139, 333-341. [CrossRef] [PubMed]

13. Mudzinski, S.P. Effects of benzo[a]pyrene on concanavalin A-stimulated human peripheral blood mononuclear cells in vitro: Inhibition of proliferation but no effect on parameters related to the G1 phase of the cell cycle. Toxicol. Appl. Pharmacol. 1993, 119, 166-174. [CrossRef] [PubMed] 
14. Gammon, M.D.; Santella, R.M.; Neugut, A.I.; Eng, S.M.; Teitelbaum, S.L.; Paykin, A.; Levin, B.; Terry, M.B.; Young, T.L.; Wang, L.W.; et al. Environmental toxins and breast cancer on Long Island. I. Polycyclic aromatic hydrocarbon DNA adducts. Cancer Epidemiol. Biomark. Prev. Publ. Am. Assoc. Cancer Res. Cosponsored Am. Soc. Prev. Oncol. 2002, 11, 677-685.

15. Li, D.; Wang, M.; Cheng, L.; Spitz, M.R.; Hittelman, W.N.; Wei, Q. In vitro induction of benzo(a)pyrene diol epoxide-DNA adducts in peripheral lymphocytes as a susceptibility marker for human lung cancer. Cancer Res. 1996, 56, 3638-3641. [PubMed]

16. Liamin, M.; Boutet-Robinet, E.; Jamin, E.L.; Fernier, M.; Khoury, L.; Kopp, B.; Le Ferrec, E.; Vignard, J.; Audebert, M.; Sparfel, L. Benzo[ $\alpha$ ]pyrene-induced DNA damage associated with mutagenesis in primary human activated T lymphocytes. Biochem. Pharmacol. 2017, 137, 113-124. [CrossRef] [PubMed]

17. Hockley, S.L.; Arlt, V.M.; Brewer, D.; Giddings, I.; Phillips, D.H. Time- and concentration-dependent changes in gene expression induced by benzo $(\alpha)$ pyrene in two human cell lines, MCF-7 and HepG2. BMC Genom. 2006, 7, 260. [CrossRef] [PubMed]

18. Sparfel, L.; Pinel-Marie, M.-L.; Boize, M.; Koscielny, S.; Desmots, S.; Pery, A.; Fardel, O. Transcriptional signature of human macrophages exposed to the environmental contaminant benzo( $\alpha)$ pyrene. Toxicol. Sci. Off. J. Soc. Toxicol. 2010, 114, 247-259. [CrossRef] [PubMed]

19. Bernshausen, T.; Jux, B.; Esser, C.; Abel, J.; Fritsche, E. Tissue distribution and function of the Aryl hydrocarbon receptor repressor (AhRR) in C57BL/6 and Aryl hydrocarbon receptor deficient mice. Arch. Toxicol. 2006, 80, 206-211. [CrossRef] [PubMed]

20. Brauze, D.; Zawierucha, P.; Kiwerska, K.; Bednarek, K.; Oleszak, M.; Rydzanicz, M.; Jarmuz-Szymczak, M. Induction of expression of aryl hydrocarbon receptor-dependent genes in human HepaRG cell line modified by shRNA and treated with $\beta$-naphthoflavone. Mol. Cell Biochem. 2017, 425, 59-75. [CrossRef] [PubMed]

21. Fu, H.; Wang, A.; Mauro, C.; Marelli-Berg, F. T lymphocyte trafficking: Molecules and mechanisms. Front. Biosci. Landmark Ed. 2013, 18, 422-440. [PubMed]

22. Munk, R.; Ghosh, P.; Ghosh, M.C.; Saito, T.; Xu, M.; Carter, A.; Indig, F.; Taub, D.D.; Longo, D.L. Involvement of mTOR in CXCL12 mediated T cell signaling and migration. PLoS ONE 2011, 6, e24667. [CrossRef] [PubMed]

23. Ticchioni, M.; Charvet, C.; Noraz, N.; Lamy, L.; Steinberg, M.; Bernard, A.; Deckert, M. Signaling through ZAP-70 is required for CXCL12-mediated T-cell transendothelial migration. Blood 2002, 99, 3111-3118. [CrossRef] [PubMed]

24. DellaValle, C.T.; Deziel, N.C.; Jones, R.R.; Colt, J.S.; De Roos, A.J.; Cerhan, J.R.; Cozen, W.; Severson, R.K.; Flory, A.R.; Morton, L.M.; et al. Polycyclic aromatic hydrocarbons: determinants of residential carpet dust levels and risk of non-Hodgkin lymphoma. Cancer Causes Control CCC 2016, 27, 1-13. [CrossRef] [PubMed]

25. Raghavan, A.; Ogilvie, R.L.; Reilly, C.; Abelson, M.L.; Raghavan, S.; Vasdewani, J.; Krathwohl, M.; Bohjanen, P.R. Genome-wide analysis of mRNA decay in resting and activated primary human $\mathrm{T}$ lymphocytes. Nucleic Acids Res. 2002, 30, 5529-5538. [CrossRef] [PubMed]

26. Ambroise, J.; Bearzatto, B.; Robert, A.; Govaerts, B.; Macq, B.; Gala, J.-L. Impact of the spotted microarray preprocessing method on fold-change compression and variance stability. BMC Bioinform. 2011, 12, 413. [CrossRef] [PubMed]

27. Hockley, S.L.; Arlt, V.M.; Brewer, D.; Te Poele, R.; Workman, P.; Giddings, I.; Phillips, D.H. AHR- and DNA-damage-mediated gene expression responses induced by benzo(a)pyrene in human cell lines. Chem. Res. Toxicol. 2007, 20, 1797-1810. [CrossRef] [PubMed]

28. Keshava, C.; Whipkey, D.; Weston, A. Transcriptional signatures of environmentally relevant exposures in normal human mammary epithelial cells: benzo[a]pyrene. Cancer Lett. 2005, 221, 201-211. [CrossRef] [PubMed]

29. Keshava, C.; Divi, R.L.; Einem, T.L.; Richardson, D.L.; Leonard, S.L.; Keshava, N.; Poirier, M.C.; Weston, A. Chlorophyllin significantly reduces benzo[a]pyrene-DNA adduct formation and alters cytochrome P450 1A1 and 1B1 expression and EROD activity in normal human mammary epithelial cells. Environ. Mol. Mutagen. 2009, 50, 134-144. [CrossRef] [PubMed]

30. Lu, X.; Shao, J.; Li, H.; Yu, Y. Early whole-genome transcriptional response induced by benzo[a]pyrene diol epoxide in a normal human cell line. Genomics 2009, 93, 332-342. [CrossRef] [PubMed]

31. Frericks, M.; Meissner, M.; Esser, C. Microarray analysis of the AHR system: tissue-specific flexibility in signal and target genes. Toxicol. Appl. Pharmacol. 2007, 220, 320-332. [CrossRef] [PubMed] 
32. Brinchmann, B.C.; Le Ferrec, E.; Podechard, N.; Lagadic-Gossmann, D.; Shoji, K.F.; Penna, A.; Kukowski, K.; Kubátová, A.; Holme, J.A.; Øvrevik, J. Lipophilic Chemicals from Diesel Exhaust Particles Trigger Calcium Response in Human Endothelial Cells via Aryl Hydrocarbon Receptor Non-Genomic Signalling. Int. J. Mol. Sci. 2018, 19, 1429. [CrossRef] [PubMed]

33. Honda, K.; Takaoka, A.; Taniguchi, T. Type I interferon [corrected] gene induction by the interferon regulatory factor family of transcription factors. Immunity 2006, 25, 349-360. [CrossRef] [PubMed]

34. Yamada, T.; Horimoto, H.; Kameyama, T.; Hayakawa, S.; Yamato, H.; Dazai, M.; Takada, A.; Kida, H.; Bott, D.; Zhou, A.C.; et al. Constitutive aryl hydrocarbon receptor signaling constrains type I interferon-mediated antiviral innate defense. Nat. Immunol. 2016, 17, 687-694. [CrossRef] [PubMed]

35. Guan, S.; Huang, Y.; Feng, Z.; Xu, L.; Jin, Y.; Lu, J. The toxic effects of benzo[a]pyrene on activated mouse T cells in vitro. Immunopharmacol. Immunotoxicol. 2017, 39, 117-123. [CrossRef] [PubMed]

36. Ciencewicki, J.; Jaspers, I. Air Pollution and Respiratory Viral Infection. Inhal. Toxicol. 2007, 19, 1135-1146. [CrossRef] [PubMed]

37. Oh, S.; Im, H.; Oh, E.; Lee, J.; Khim, J.; Mun, J.; Kim, Y.; Lee, E.; Kim, J.; Sul, D. Effects of benzo(a)pyrene on protein expression in Jurkat T-cells. Proteomics 2004, 4, 3514-3526. [CrossRef] [PubMed]

38. Trifilo, M.J.; Bergmann, C.C.; Kuziel, W.A.; Lane, T.E. CC chemokine ligand 3 (CCL3) regulates CD8(+)-T-cell effector function and migration following viral infection. J. Virol. 2003, 77, 4004-4014. [CrossRef] [PubMed]

39. Yao, L.; Pan, J.; Setiadi, H.; Patel, K.D.; McEver, R.P. Interleukin 4 or oncostatin M induces a prolonged increase in P-selectin mRNA and protein in human endothelial cells. J. Exp. Med. 1996, 184, 81-92. [CrossRef] [PubMed]

40. Nedelkovska, H.; Rosenberg, A.F.; Hilchey, S.P.; Hyrien, O.; Burack, W.R.; Quataert, S.A.; Baker, C.M.; Azadniv, M.; Welle, S.L.; Ansell, S.M.; et al. Follicular Lymphoma Tregs Have a Distinct Transcription Profile Impacting Their Migration and Retention in the Malignant Lymph Node. PLoS ONE 2016, 11. [CrossRef] [PubMed]

41. Kim, Y.; Bae, Y.S.; Park, J.C.; Suh, P.G.; Ryu, S.H. The synthetic peptide, His-Phe-Tyr-Leu-Pro-Met, is a chemoattractant for Jukat T cells. Exp. Mol. Med. 2001, 33, 257-262. [CrossRef] [PubMed]

42. Nguyen, P.M.; Park, M.S.; Chow, M.; Chang, J.H.; Wrischnik, L.; Chan, W.K. Benzo[a]pyrene increases the Nrf2 content by downregulating the Keap1 message. Toxicol. Sci. Off. J. Soc. Toxicol. 2010, 116, 549-561. [CrossRef] [PubMed]

43. Amiot, L.; Vu, N.; Rauch, M.; L’Helgoualc'h, A.; Chalmel, F.; Gascan, H.; Turlin, B.; Guyader, D.; Samson, M. Expression of HLA-G by mast cells is associated with hepatitis $C$ virus-induced liver fibrosis. J. Hepatol. 2014, 60, 245-252. [CrossRef] [PubMed]

44. Foster, G.R.; Masri, S.H.; David, R.; Jones, M.; Datta, A.; Lombardi, G.; Runkell, L.; de Dios, C.; Sizing, I.; James, M.J.; et al. IFN- $\alpha$ Subtypes Differentially Affect Human T Cell Motility. J. Immunol. 2004, 173, 1663-1670. [CrossRef] [PubMed]

45. De Waard, W.J.; Aarts, J.M.M.J.G.; Peijnenburg, A.C.M.; Baykus, H.; Talsma, E.; Punt, A.; de Kok, T.M.C.M.; van Schooten, F.J.; Hoogenboom, L.P. Gene expression profiling in Caco-2 human colon cells exposed to TCDD, benzo[a]pyrene, and natural Ah receptor agonists from cruciferous vegetables and citrus fruits. Toxicol. In Vitro Int. J. Publ. Assoc. BIBRA 2008, 22, 396-410. [CrossRef] [PubMed]

46. Kendziorski, C.M.; Zhang, Y.; Lan, H.; Attie, A.D. The efficiency of pooling mRNA in microarray experiments. Biostat. Oxf. Engl. 2003, 4, 465-477. [CrossRef] [PubMed]

47. Gentleman, R.C.; Carey, V.J.; Bates, D.M.; Bolstad, B.; Dettling, M.; Dudoit, S.; Ellis, B.; Gautier, L.; Ge, Y.; Gentry, J.; et al. Bioconductor: Open software development for computational biology and bioinformatics. Genome Biol. 2004, 5, R80. [CrossRef] [PubMed]

48. Piccolo, S.R.; Withers, M.R.; Francis, O.E.; Bild, A.H.; Johnson, W.E. Multiplatform single-sample estimates of transcriptional activation. Proc. Natl. Acad. Sci. USA 2013, 110, 17778-17783. [CrossRef] [PubMed]

49. Dai, M.; Wang, P.; Boyd, A.D.; Kostov, G.; Athey, B.; Jones, E.G.; Bunney, W.E.; Myers, R.M.; Speed, T.P.; Akil, H.; et al. Evolving gene/transcript definitions significantly alter the interpretation of GeneChip data. Nucleic Acids Res. 2005, 33, e175. [CrossRef] [PubMed]

50. Barrett, T.; Wilhite, S.E.; Ledoux, P.; Evangelista, C.; Kim, I.F.; Tomashevsky, M.; Marshall, K.A.; Phillippy, K.H.; Sherman, P.M.; Holko, M.; et al. NCBI GEO: Archive for functional genomics data sets-Update. Nucleic Acids Res. 2013, 41, D991-D995. [CrossRef] [PubMed] 
51. Darde, T.A.; Gaudriault, P.; Beranger, R.; Lancien, C.; Caillarec-Joly, A.; Sallou, O.; Bonvallot, N.; Chevrier, C.; Mazaud-Guittot, S.; Jégou, B.; et al. TOXsIgN: A cross-species repository for toxicogenomic signatures. Bioinform. Oxf. Engl. 2018, 34, 2116-2122. [CrossRef] [PubMed]

52. Chalmel, F.; Primig, M. The Annotation, Mapping, Expression and Network (AMEN) suite of tools for molecular systems biology. BMC Bioinform. 2008, 9, 86. [CrossRef] [PubMed]

53. Mayati, A.; Podechard, N.; Rineau, M.; Sparfel, L.; Lagadic-Gossmann, D.; Fardel, O.; Le Ferrec, E. Benzo(a)pyrene triggers desensitization of $\beta 2$-adrenergic pathway. Sci. Rep. 2017, 7, 3262. [CrossRef] [PubMed]

(C) 2018 by the authors. Licensee MDPI, Basel, Switzerland. This article is an open access article distributed under the terms and conditions of the Creative Commons Attribution (CC BY) license (http://creativecommons.org/licenses/by/4.0/). 